\title{
Antineoplastic potential of the aqueous crude extract of Eugenia uniflora L. in human cervical cancer
}

\author{
Jisette González Núñez ${ }^{1}$, Jordânia dos Santos Pinheiro', Gabriel Fernandes Silveira ${ }^{1}$, Aline \\ Beckenkamp $^{2}$, Andréia Buffon ${ }^{2}$, Alessandra Nejar Bruno ${ }^{1 *}$
}

\begin{abstract}
${ }^{1}$ Department of Biotechnology of the Federal Institute of Education, Science and Technology of Rio Grande do Sul, Campus Porto Alegre, Porto Alegre, Rio Grande do Sul, Brazil, ${ }^{2}$ School of Pharmacy, Federal University of Rio Grande do Sul, Porto Alegre, Rio Grande do Sul, Brazil
\end{abstract}

\begin{abstract}
Considering the high prevalence of human cervical cancer and the adverse effects of the available treatments, it is important to develop studies involving plants. Eugenia uniflora L. is a Brazilian native plant widely used in folk medicine and some biological effects have already been described. In this study, we investigated the biologicals effects of the aqueous crude extract of $E$. uniflora leaves in relation to the viability of human cervical cancer cells ( $\mathrm{SiHa}$ ), non-tumorigenic cells $\mathrm{HaCaT}$ and human lymphocytes. Our results demonstrated that different concentrations of E. uniflora's extract significantly inhibited the viability of the Siha cell line at 24, 48 and 72 hours of treatment, but did not induce significant changes in the HaCat cell line and human lymphocytes. Tumor cells had adhesion capacity, migration processes, ability of colony forming and the potential to recover its viability after treatment. withdrawal, significantly reduced. The nuclear morphology revealed chromatin condensation, and the flow cytometry showed predominantly cell death by apoptosis in the treated tumor cells. Therefore, the E. uniflora's extract may contribute for future studies aiming at new therapeutic perspectives for human cervical cancer.
\end{abstract}

Keywords: Eugenia uniflora L./effects/antitumoral. Pitangueira. SiHa. HaCat. Plant extract/antitumoral. Cervical cancer.

\section{INTRODUCTION}

Cervical cancer remains a disease of high prevalence, incidence, and mortality, and it is the fourth most common cancer in women and the seventh overall (Siegel, Miller, Jemal, 2016). In developing countries such as Brazil, this pathology has maintained high levels of incidence, (with an increase of $29 \%$ comparing the last two decades) and thus it is the fourth cause of cancer death in women in Brazil (Brasil, 2015). Squamous cell carcinoma accounts for approximate $80 \%$ of cervical carcinoma, whereas adenocarcinoma is less common and accounts for $20 \%$ of cervical carcinoma (Parkin, Bray, 2006). Cervical cancer occurs in people of all ages, including relatively young age groups, and sexual transmission of human papilloma virus (HPV) is the major etiological factor (Walboomers et al., 1999).

\footnotetext{
*Correspondence: A. N. Bruno. Departamento de Biotecnologia, Instituto Federal de Educação, Ciência e Tecnologia, Campus Porto Alegre, Porto Alegre, Rio Grande do Sul, Brasil. Email: alessandra.bruno@poa.ifrs.edu.br
}

Unfortunately, the data indicates increased longterm risk for invasive cervical cancer in women after treatment of cervical intraepithelial neoplasia (Soutter, Sasieni, Panoskaltsis, 2006) and a high recurrence rate of cervical cancer after radical hysterectomy (Mabuchi, Kozasa, Kimura, 2017).

For these reasons, many studies based on plant have been seeking antiproliferative or cytotoxic activities for tumor cells, in search of new antineoplastic agents.

Eugenia uniflora L., Myrtaceae, is a plant widely found in Brazil, Argentina, Paraguay and Uruguay (Lima, Mélo, Lima, 2005). Infusions or decoctions made from the leaves of this plant are commonly used in folk medicine as antidiarrheic, diuretic, antirheumatic, antihypertensive, astringent, antipyretic, and for the treatment of digestive disorders (Bandoni et al., 1972; Fiuza, Rezende, Sabóia-Morais, 2008). Previous studies demonstrated that leaf extracts of Eugenia uniflora were slightly active on lipid metabolism, exerted a protective effect on triglycerides and very low-density lipoprotein levels (Ferro et al., 1988) and had a highly significant 
anti-inflammatory action (Schapoval et al., 1994). Consolini and Sarubbio (2002) showed that the aqueous crude extract of E. uniflora leaves had a hypotensive effect mediated by direct vasodilation and diuretic activity. Other biological effects have been described in the literature, such as antioxidant (Lima, Mélo, Lima, 2002), antimicrobial (Bouzada et al., 2009) and hypoglycemic (Lee et al., 2000).

The phytochemical screening of the leaves demonstrated the presence of flavonoids, triterpenes and saponins (Alice et al., 1991). Others studies also proved this composition and identified the presence of tannins, triterpenes, anthraquinoneheterosides and steroids (Fiuza, Rezende, Sabóia-Morais, 2008). Plants rich in tannins are used in the traditional medicine to treat diarrhea, hypertension, rheumatism, bleeding, wounds, burns, stomach problems, kidney and urinary tract problems and inflammatory processes in general (Simões, 2006). Polyphenolic compounds like flavonoids have an enormous range of biological actions that include anti-inflammatory, antiallergenic, antiviral, antibacterial, antifungal, antitumor and antihemorrhagic (Formica, Regelson, 1995; Slowing, Carretero, Villar, 1994). Furthermore, in a previous study leaf extracts of E. uniflora have shown antioxidant activity, and polyphenolic compounds are implicated in this activity (Reynertson, Basile, Kennelly, 2005). Despite these researches, there are no reports describing the possible antitumor effects of E. uniflora on cervical cancer cells. Therefore, in this study we intend to investigate the biological effects of aqueous crude extract from leaves of E. uniflora in relation to the viability of human cervical cancer cells, as well as verify if this extract affects the viability of non-tumorigenic cells.

\section{MATERIAL AND METHODS}

\section{Material}

Penicillin/gentamicin, fungizone (amphotericin B) and fetal bovine serum (FBS) were purchased from Gibco (Gibco BRL, Grand Island, NY). Dulbecco's modified Eagle's medium (DMEM), RPMI-1640, trypsin/EDTA solution, Trypan Blue dye, Hoechst ${ }^{\circledR} 33258$ stain, Ficoll (Histopaque $\left.{ }^{\circledR}\right)$ and MTT (3-[4,5-dimethylthiazol-2yl]-2,5-diphenyl tetrazolium bromide) were purchased from Sigma Aldrich (St. Louis, MO, USA). Annexin V Apoptosis Detection Kit was purchased from Santa Cruz Biotechnology, Inc, Santa Cruz, CA. All other chemicals and solvents used were of analytical grade.

\section{Plant material}

Leaves of E. uniflora were collected and botanically identified, washed, disinfected with sodium hypochlorite $2 \%$ and then washed with deionized water. The vegetal material was dried in incubator at $60{ }^{\circ} \mathrm{C}$ for 3 days, and after dehydration, the leaves were crushed. The powder was dissolved in DMEM medium, heated to $40{ }^{\circ} \mathrm{C}$ under stirring for 1 hour. The solution was then centrifuged at $2,000 \mathrm{rpm}$ for 20 minutes and the supernatant was filtered with a membrane filter $(0,22 \mu \mathrm{m})$, and used in the different assays.

\section{Cell lines maintenance}

The human cell line derived from invasive cervical carcinoma, SiHa (HPV 16-positive) was obtained from American Type Culture Collection (ATCC - Rock-Ville, $\mathrm{MD}$ ) and the immortalized human keratinocytes, HaCaT, were kindly donated by Dr. Luisa L. Villa (ICESP, School of Medicine, University of São Paulo) and Dr. Silvya S. Maria-Engler (School of Pharmaceutical Sciences, University of São Paulo). Cell lines were cultured in DMEM supplemented with $10 \%$ FBS, $100 \mu \mathrm{g} / \mathrm{mL}$ streptomycin and $0.5 \mu \mathrm{g} / \mathrm{mL}$ fungizone. The cell culture was maintained at $37^{\circ} \mathrm{C}$ in $5 \% \mathrm{CO}_{2}$ atmosphere.

\section{Human lymphocytes culture}

Human lymphocytes were used as non-tumorigenic cells control for the investigation of toxic effects on normal cells. For this, human peripheral blood was diluted with RPMI and centrifuged with Ficoll (Histopaque ${ }^{\circledR}$ ). After, the fraction enriched with mononuclear cells were centrifuged for washing, counted and plated for further assays. The cells were maintained in $5 \% \mathrm{CO}_{2}$ incubator at $37{ }^{\circ} \mathrm{C}$ with RPMI-1640 medium supplemented with $10 \%$ FBS, $100 \mu \mathrm{g} / \mathrm{mL}$ streptomycin and $0.5 \mu \mathrm{g} / \mathrm{mL}$ fungizone.

\section{Cell viability analysis}

The viability of SiHa and HaCat cells was determined using the MTT (3-[4,5-dimethylthiazol-2-yl]-2,5-diphenyl tetrazolium bromide) assay. Briefly, suspensions of cells were seeded in 96-well plates at densities of $2.8 \times 10^{3}$ cells/ well and maintained to grow to confluence in incubator at $37{ }^{\circ} \mathrm{C}$ in $5 \% \mathrm{CO}_{2}$. After cell adhesion, the supernatant was aspirated and the cells were treated with the aqueous crude extracts at different concentrations $(0.5,1.5,2.5,5$, 10,15 and $20 \mathrm{mg} / \mathrm{mL}$ ) for 24,48 and 72 hours. Controls were prepared using only DMEM medium. 
After withdrawn treatment, MTT solution $(0.5 \mathrm{mg} /$ $\mathrm{mL}$ ) was added to each well and plates were incubated for 3.5 hours at $37^{\circ} \mathrm{C}$. Formazan crystals formed by tetrazolium cleavage were dissolved with Dimethyl Sulfoxide (DMSO) and quantified at 570 and $630 \mathrm{~nm}$ using an EnVision Multilabel Plate Reader (PerkinElmer). The results were expressed as percentage of control, which was considered as $100 \%$ of cell viability. IC50 values were calculated from log dose-response curves using GraphPad Prism 5 software.

In order to analyze the viability of human lymphocytes, these cells were seeded in a 96-well plate $\left(8 \times 10^{3}\right.$ cells/well $)$ and maintained in an incubator at $37^{\circ} \mathrm{C}$ in $5 \% \mathrm{CO}_{2}$. The cells were treated with the different concentrations of extract $(0.5,1.5,2.5,5,10,15$ and $20 \mathrm{mg} / \mathrm{mL}$ ) for 24 hours. Then, the suspension of cells was diluted with Trypan Blue $(1: 1 \mathrm{v} / \mathrm{v})$ to selectively stain dead cells, and viable cells (trypan blue negative) were counted by Neubauer chamber in an optical microscope. Controls were prepared using only RPMI medium.

\section{Wound healing assay}

The cell migration was measured using the wound healing assay as described by Rodriguez, Wu and Guan (2005). Briefly, SiHa cells were seeded in 24-well plates $\left(2.8 \times 10^{4}\right.$ cells/well $)$ and grown to confluence. The confluent cell monolayer was carefully wounded using a pipette tip. Then, the cellular debris were removed by washing with PBS and the wounds were photographed before and after treatment with extract at IC50 $(7.8 \mathrm{mg} /$ $\mathrm{mL})$ concentration. The cell migration into the scratched region was recorded using an Olympus CK40 microscopy system coupled to an UCMOS 03100 KPA digital camera before treatment, and then 24 and 48 hours after treatment. The cells that migrated across the reference line in treated and control dishes were counted and averaged. The results were calculated by comparing the wound width before and after treatment in treated and control dishes.

\section{Adhesion assay}

SiHa cells were plated $\left(2.8 \times 10^{4}\right.$ cells/well $)$ in 24 well plates and immediately treated with crude extract of E. uniflora at 5,10 and $20 \mathrm{mg} / \mathrm{mL}$ for 24 hours. After this period, aliquots of cellular suspension from each well were removed and mixed with trypan blue dye exclusion for counting of unadhered viable cells using hemocytometer. Results were expressed as the number of viable treated cells which had not adhered in comparison with the control.

\section{Clonogenic assay}

The clonogenic ability following treatment with crude extract of E. uniflora in cancer cells was performed by using clonogenic assay as described by Franken et al. (2006). For this purpose SiHa cells $\left(2.8 \times 10^{4}\right.$ cells $/$ well) were seeded in a 24 -well plate and after adhesion, the subconfluent cultures were treated with an extract at IC50 $(7.8 \mathrm{mg} / \mathrm{mL})$ for 24 hours. The adherent cells from treated and control dishes were then washed with PBS, trypsinized, counted in hemocytometer, and replated in six-well plates (100 cells/well). After 10 days of incubation, the formed colonies were stained with crystal violet after fixation with methanol and counted manually. The results were expressed as survival fraction, which was obtained by dividing the number of colonies that arise after treatment by the number of cells seeded and plate efficiency (PE: number of colonies formed by untreated cells/number of cells seeded), multiplied by 100 (Franken et al., 2006).

\section{Washout assay}

The recovery capacity after withdrawal of treatment was determined by Washout Assay. SiHa cells $(2.8 \times$ $10^{4}$ cells/well) were seeded in a 24 -well plate and after adhesion, the subconfluent cultures were treated with an extract at IC50 $(7.8 \mathrm{mg} / \mathrm{mL})$ concentration for 24 hours. The adherent cells were then washed with PBS to remove the entire treatment, trypsinized, counted and replated in 96-well plates (2.800 cells/well). After that, the cells were incubated for 4 days at standard conditions, and the MTT assay was used to measure cell viability as described before (Cell Viability Analysis section).

\section{Hoechst stain}

The morphological changes occurring during apoptosis were evaluated using the fluorescent Hoechst ${ }^{\circledR}$ 33258 stain. SiHa cells $\left(2.8 \times 10^{4}\right.$ cells/well $)$ were seeded in a 24 -well plate containing glass coverslips. After adhesion, the cells were treated with aqueous crude extract of leaves of E. uniflora at concentration of $7.8 \mathrm{mg} / \mathrm{mL}$ (IC 50 ) for 24 hours. Afterwards, the cells were washed with PBS and fixed with paraformaldehyde $4 \%$ for 20 minutes. The cells were then stained with Hoechst ${ }^{\circledR} 33258(1 \mu \mathrm{g} /$ $\mathrm{mL}$ ) for 20 minutes at room temperature. The coverslips were removed for blade mounting and cell morphology analysis. Photography was obtained using fluorescence microscope BIOVAL- L2000A coupled to an OPTON digital camera. 


\section{Annexin V /Propidium iodide staining}

The phosphatidylserine externalization was determined by the annexin fluorescence signal of an annexin V-fluorescein isothiocyanate conjugate (Santa Cruz Biotechnology, Inc, Santa Cruz, CA) according to the manufacturer's protocol. SiHa cells were treated for 24 and 48 hours with aqueous crude extract of $E$. uniflora, trypsinized and centrifuged at $1600 \mathrm{rpm}$. The pellet was resuspended with annexin binding buffer (10 $\mathrm{mM}$ 4-(2-hydroxyethyl)-1-piperazine ethanosulfonic acid, $\mathrm{pH} 7.4,140 \mathrm{mM} \mathrm{NaCl}, 2.5 \mathrm{mM} \mathrm{CaCl}$ ), incubated with annexin $\mathrm{V}$ and $\mathrm{PI}$ at room temperature in the dark and analyzed on a Guava EasyCyte flow cytometer, using Guava EasyCyte software for analysis (Millipore, Billerica, MA).

\section{Statistical analysis}

All of the values were expressed as averages and standard deviation (SD) from at least three independent experiments performed in triplicate. The data was analyzed using one way analysis of variance (ANOVA) followed by the Tukey test using the GraphPad Prism 5 (San Diego, USA, 2007). Statistical differences were considered significant when the value was $\mathrm{p}<0.05$.

\section{RESULTS}

\section{E. uniflora aqueous crude extract promotes cancer cell death}

Parameters such as concentrations and treatment times were standardized using a cell viability assay with different concentrations (from $0.5 \mathrm{mg} / \mathrm{mL}$ to $20 \mathrm{mg} / \mathrm{mL}$ ) of the aqueous crude extract obtained from the leaves of E. uniflora in human cervical cancer cells ( $\mathrm{SiHa}$ ).

Throughout the MTT assay it was observed that different concentrations of the aqueous crude extract significantly inhibited the viability of $\mathrm{SiH}$ a cells in relation to the control in all the three times tested. At 24 hours of treatment, the inhibition was between $17 \%$ and $41 \%$ (Figure 1A); at 48 hours of treatment, it was between $35 \%$ and $65 \%$ (Figure 1B), and at 72 hours of treatment, it was between $11 \%$ and $61 \%$ (Figure 1C). Based on the cell viability tests, it was possible to obtain the half maximal inhibitory concentration (IC50) of $7.8 \mathrm{mg} / \mathrm{mL}$ for the aqueous crude extract in $\mathrm{SiHa}$ cell line at 24 hours of treatment.

In contrast, the different concentrations of the aqueous crude extract of E. uniflora induced an increase
A
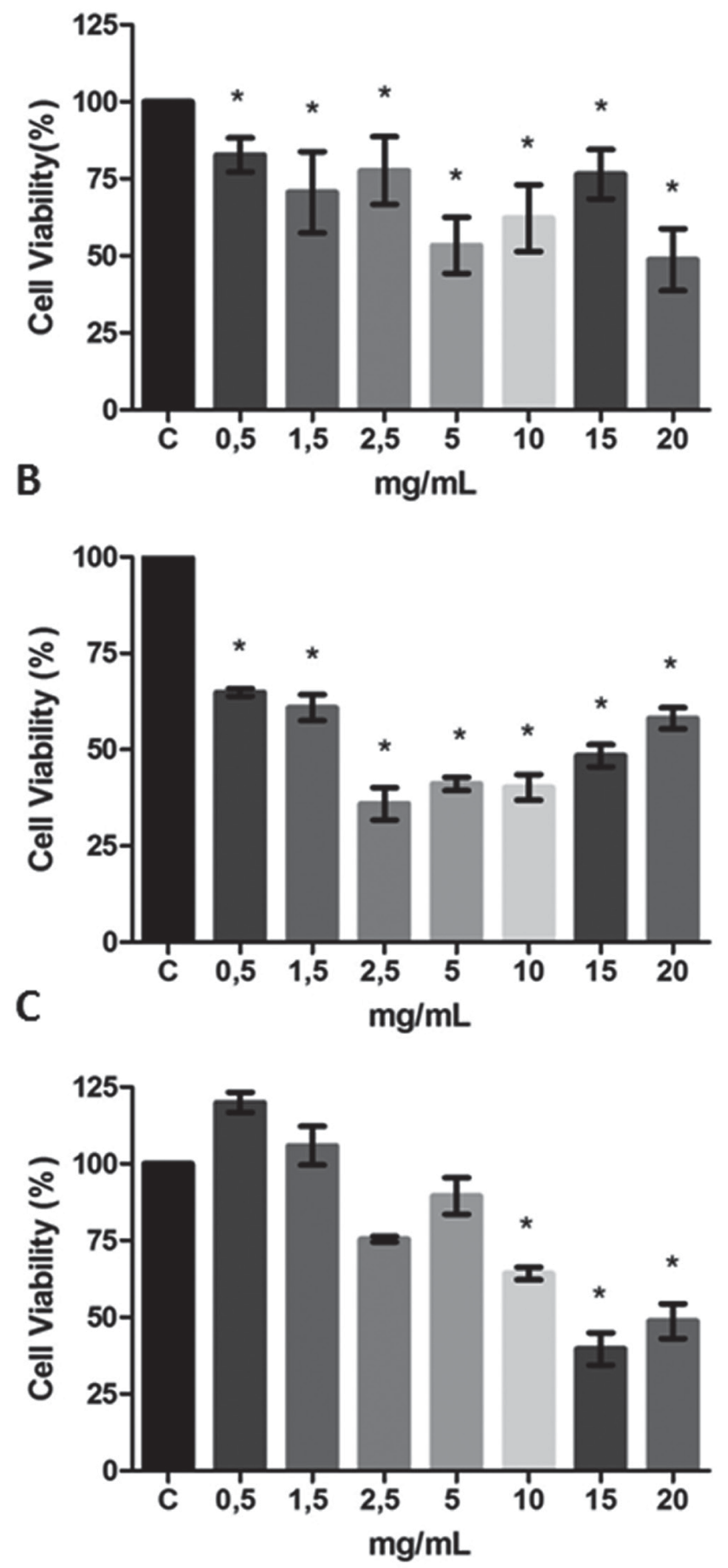

FIGURE 1 - Effects of treatment with different concentrations of E. uniflora aqueous crude extract in relation to the viability of cervical carcinoma cells ( $\mathrm{SiHa}$ ) for 24 hours (A), 48 hours (B) and 72 hours (C). Data show mean and standard deviation of 3 independent experiments performed in triplicate. ${ }^{*} \mathrm{P}<0.05$ (One-way ANOVA followed by Tukey's test).

of cell viability until $10 \mathrm{mg} / \mathrm{mL}$ and a cytotoxic effect at 15 and $20 \mathrm{mg} / \mathrm{mL}$ in the non-tumor cells used (HaCaT) at 
24 hours of treatment (Figure 2A).

We also tested the aqueous crude extract of $E$. uniflora to verify cytotoxicity in primary cultures of human lymphocytes as a non-tumor control using concentrations between 0.5 and $20 \mathrm{mg} / \mathrm{mL}$. The results demonstrated that treatment did not inhibit significantly the lymphocytes viability when compared to control in most of the different concentrations tested (Figure 2B).
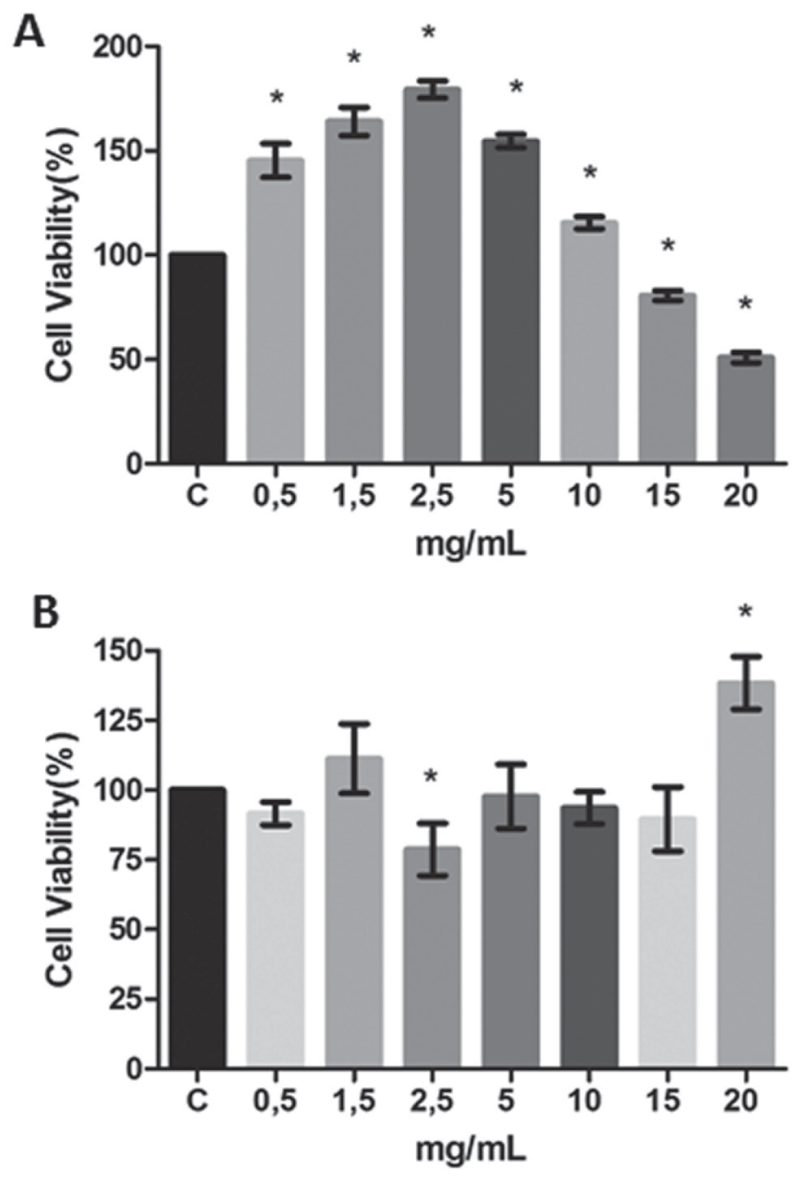

FIGURE 2 - (A) Effect of treatment with different concentrations of $E$. uniflora aqueous crude extract in relation to the viability of immortalized human keratinocytes cell line (HaCaT) for 24 hours. (B) Effect of treatment with different concentrations of E. uniflora aqueous crude extract on the viability of human lymphocytes for 24 hours. Data show mean and standard deviation of 3 independent experiments performed in triplicate. $* \mathrm{P}<0.05$ (One-way ANOVA followed by Tukey's test).

\section{E. uniflora aqueous crude extract affects cell migration and adhesion}

Apart from the observed inhibition on the cell viability, the investigation of the aqueous crude extract of E. uniflora effects in relevant indicators for SiHa cells also demonstrated significant results.
The Wound Healing method was performed to determine the rate of cell migration. This method is based on the observation that, upon creation of a "wound" on a confluent cell monolayer, the cells on the edge of this wound will move toward the opening until new cell-cell contacts are established again (Liang, Park, Guan, 2007).

In Figure 3A we can observe a picture of the wounds in the cell monolayer before and after the treatment. The tumor cells had their migration process significantly reduced after treatment with the E. uniflora aqueous crude extract $(7.8 \mathrm{mg} / \mathrm{mL}$ ) at 24 hours (for $63.4 \%$ ) and at 48 hours (for $24.5 \%$ ) as seen in Figure 3B.

The tumor cell-adhesion capacity was also significantly inhibited by the treatment with E. uniflora aqueous crude extract in the different tested concentrations. It was observed an increase in the number of unadhered viable cells while increasing extract concentration determining a dose-dependent relation (Figure 3C).

\section{Clonogenic ability and capacity to regrow after treatment exposure are impaired}

Another significant parameter to evaluate the effect of a treatment on cancer cells is the colony-forming capacity. Clonogenic assay is a method used to determine the fraction of seeded cells that retain the capacity to produce colonies and, for this reason, it is useful to determine the effectiveness of cytotoxic agents (Franken et al., 2006; Mello et al., 2014)

Figure 4A shows that the treatment markedly reduced the number of colonies formed in relation to control. These results were quantified and revealed that the treatment with the E. uniflora aqueous crude extract at $7.8 \mathrm{mg} / \mathrm{mL}$ for 24 hours was able to significantly inhibit the number of colonies formed for $81 \%$, and thus, the clonogenic capacity of SiHa cells (Figure 4B).

To determine the persistence of the effects of treatment exposure in cancer cells, we evaluated the cell viability after the removal of the extract.

In Figure 4C it was also possible to observe that only $2 \%$ of the treated cells were able to recover the viability even after the removal of the treatment with E. uniflora aqueous crude extract.

\section{Cell death induced by $E$. uniflora aqueous crude extract shows features of apoptosis}

The analysis of nuclear morphology was performed using fluorescent dye Hoechst ${ }^{\circledR}$ 33258. The results showed a fluorescence increase in the treated $\mathrm{SiHa}$ cells pointing out a greater chromatin condensation and, therefore, a 
A

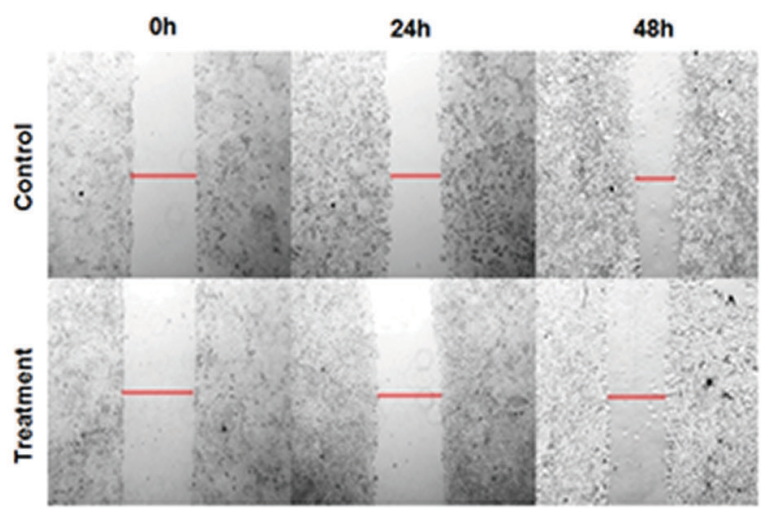

B

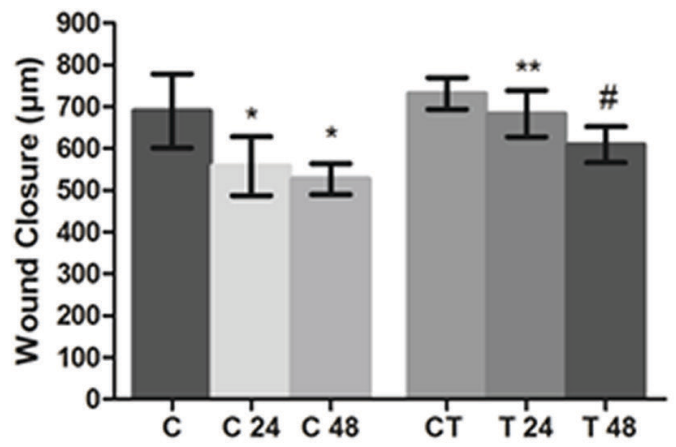

C

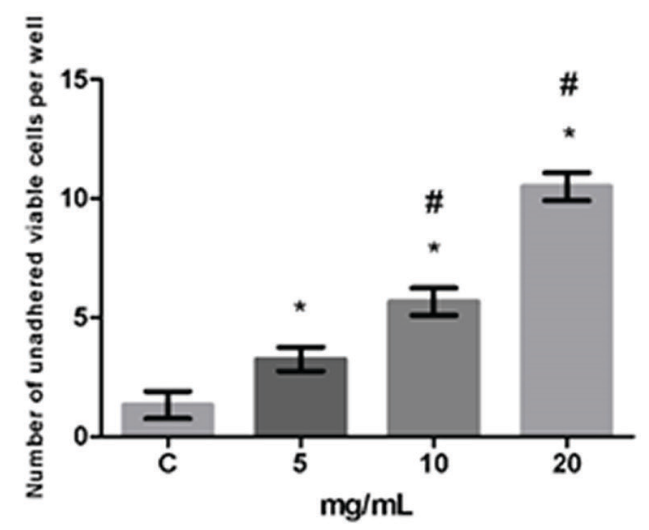

FIGURE 3 - Representative pictures (A) and measurement (B) of the effect of E. uniflora aqueous crude extract $(7.8 \mathrm{mg} /$ $\mathrm{mL}$ ) on the migration capacity of SiHa cells after 24 and 48 hours of treatment. Data show mean and standard deviation of 3 independent experiments performed in triplicate. $* \mathrm{P}<0.05$ : statistically different in relation to control before treatment $(\mathrm{C} 0)$, ** $\mathrm{P}<0.05$ : statistically different in relation to control after 24 hours (C24), \#P<0.05: statistically different in relation to control of treatment (CT) (One-way ANOVA followed by Tukey's test). (C) Effect of treatment with different concentrations of $E$. uniflora aqueous crude extract on the adhesion capacity of $\mathrm{SiHa}$ cells for 24 hours. Results were expressed as the number of viable treated cells which were not adhered in comparison with the control. Data show mean and standard deviation of 3 independent experiments performed in triplicate. ${ }^{*} \mathrm{P}<0.05$ in relation to control, \# P $<0.05$ in relation to $5 \mathrm{mg} / \mathrm{mL}$ (One-way ANOVA followed by Tukey's test).
A
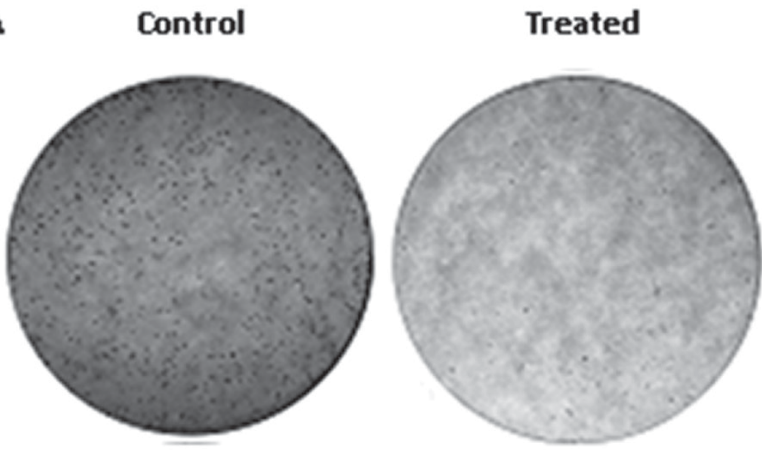

B

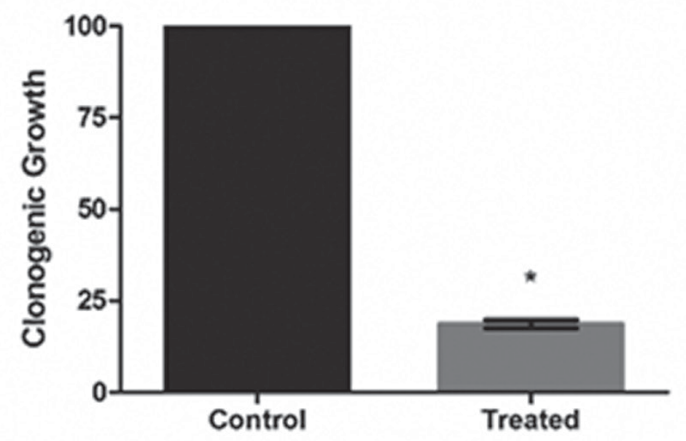

C

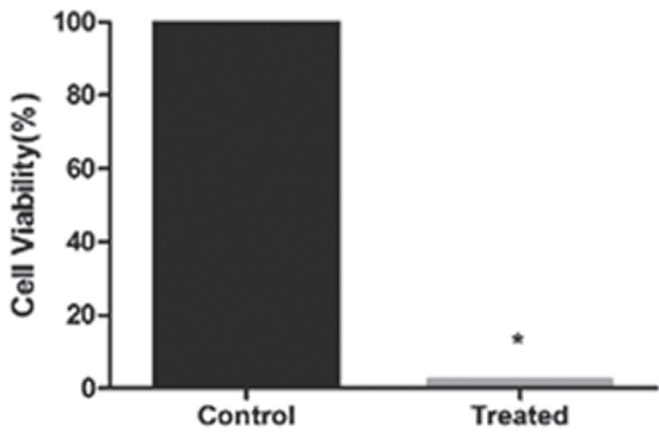

FIGURE 4 - Representative pictures (A) and measurement (B) of the effect of E. uniflora aqueous crude extract $(7.8 \mathrm{mg} / \mathrm{mL})$ on the clonogenic capacity of $\mathrm{SiHa}$ cells for 24 hours of treatment. (C) Analysis of the cell viability through the washout assay after 24 hours of treatment with the E. uniflora aqueous crude extract (at $7.8 \mathrm{mg} / \mathrm{mL}$ ). Data show mean and standard deviation of 3 independent experiments performed in triplicate. ${ }^{*} \mathrm{P}<0.05$ (One-way ANOVA followed by Tukey's test).

possible cell death via apoptosis (Figure 5A). The data obtained through flow cytometry and double staining for annexin $\mathrm{V} /$ propidium iodide showed that $1.39 \%$ of the tumor cells were marked for annexin $\mathrm{V}$ after 24 hours and $40.06 \%$ after 48 hours of treatment, while $3.44 \%$ of the tumor cells were marked for propidium iodide after 24 hours of treatment and $1.33 \%$ after 48 hours (Figure 5B). It determines a predominantly cell death by apoptosis in the tumor cells treated for 48 hours with the E. uniflora aqueous crude extract. 


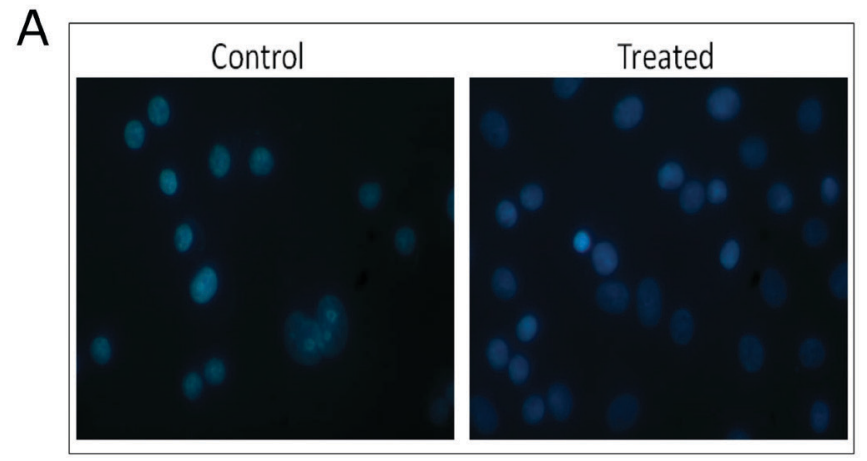

B

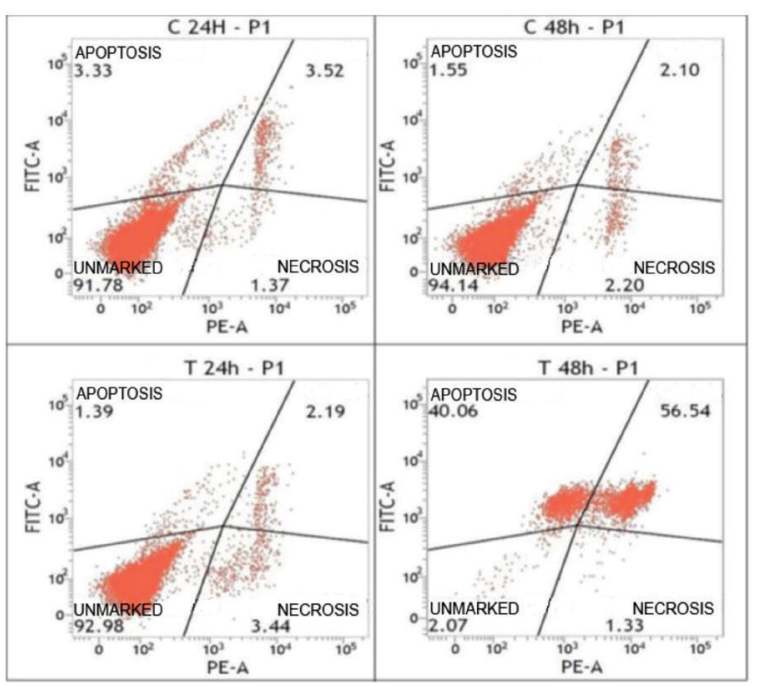

FIGURE 5 - (A) Analysis of nuclear morphology in fluorescence microscope using Hoechst ${ }^{\circledR} 33258$ dye (at $1 \mu \mathrm{g} / \mathrm{mL}$ ) in SiHa cells treated with the E. uniflora aqueous crude extract (at 7.8 $\mathrm{mg} / \mathrm{mL}$ ) for 24 hours. (B) Flow cytometry analysis of the cell death mechanism by the labeling with annexin $\mathrm{V} /$ propidium iodide in $\mathrm{SiHa}$ cells treated with the E. uniflora aqueous crude extract (at $7.8 \mathrm{mg} / \mathrm{mL}$ ) for 24 and 48 hours.

\section{DISCUSSION}

Plant-derived compounds have been an important source of several clinically useful anti-cancer agents. In this study we observed that treatment with the aqueous crude extract obtained from the leaves of E. uniflora was able to change many relevant cell parameters for growth, expansion and survival of human cervical cancer cells. Different concentrations of the aqueous crude extract of E. uniflora significantly inhibited the viability of human cervical cancer cells at 24, 48 and 72 hours of treatment, but did not inhibit the viability of both non-tumor cells tested (immortalized human keratinocytes - $\mathrm{HaCaT}$ and primary cultures of human lymphocytes). These results are encouraging, since a balance between therapeutic versus toxicological effects of the compound is important when determining its applicability as a pharmacological alternative. In addition to that, a number of promising new agents are in clinical development based on the selective activity against cancer-related molecular targets. Nevertheless, it is known that one major challenge in anticancer therapy is to increase the selectivity of current treatments against cancer cells in order to spare normal cells.

With regard to our results, the real targets of the constituents of E. uniflora plant extract in tumoral cells must be specified in future studies. Since, chemical investigation showed quercetin as the major components of E. uniflora leaves (Rattmann et al., 2012), in this study human cervical cancer cells were treated with different concentrations of this flavonoid (data not shown). However, this treatment did not induce significant changes on the viability of the tested tumor cells, demonstrating that our results cannot be attributed to quercetin. Even so, it is still necessary to test other molecules already described in the composition of this plant species. However, the contribution of different molecules that acting synergistically to the observed biological effects cannot be ruled out. The use of 'whole extract versus single-isolated constituent' has been an issue of ongoing debate the past several years. In addition to this, accumulating evidence show the existence of synergistic interactions among phytochemicals.

The benefits of E. uniflora are usually attributed to the presence of many secondary metabolites present in the leaves, which include many volatile terpenoid oils, flavonoids, and condensed and hydrolysable tannins, leucoanthocyanidins, and steroids and/or triterpenoids (Amorim et al., 2009). Flavonoids presented in many plant extracts, have been constantly the focus of pharmacological studies, especially by antioxidant effects already demonstrated (Cacciola et al., 2007). It is known that damaging free radicals and reactive oxygen species (ROS) produced naturally through oxidative metabolism have also been linked to some cancers (Jacob, Burri, 1996).

In addition to effects on cell viability, the treatment with the aqueous crude extract from E. uniflora induced significant effects on relevant indicators for human cervical cancer cells, such as inhibition of the adhesion and migration processes of these cells. We verified the cell migration by using Wound Healing assay that is a simple method, inexpensive, capable of evaluating the cell migration by cell interaction with extracellular matrix and cell-cell interactions, and mimics to some extent the migration of cells in vivo (Liang, Park, Guan, 2007). 
It is known that, cell migration is a fundamental feature of the interaction of cells with their surroundings. Migration of tumor cells has been extensively studied due to its importance in the process of metastasis (Yamaguchi, Wyckoff, Condeelis, 2005).

Metastasis is also facilitated by cell-cell interactions between tumor cells and the endothelium that contribute to tumor cell adhesion, extravasation, and the establishment of metastatic lesions (Bendas, Borsig, 2012). Some families of cell adhesion molecules such as selectins and integrins have been identified as participants in metastasis (Paschos, Canovas, Bird, 2009) and may be important targets of the components present in the plant extract used.

Considering that adhesion and migration of cancer cells play a critical role in the metastatic cascade, inhibition of these processes may represent targets for therapeutic strategies focused on developing not only tumors, but also metastases.

Furthermore, our results by using clonogenic assay showed that the treatment with E. uniflora aqueous crude extract was able to significantly inhibit the colony-forming capacity of tumor cells. The Clonogenic cell survival assay determines the ability of a cell to proliferate indefinitely, thereby retaining its reproductive ability to form a large colony or a clone. Clonogenic assay is the method of choice to determine cell reproductive death after treatment with ionizing radiation, but can also be used to determine the effectiveness of other cytotoxic agents (Franken et al., 2006).

When treated viable cells were seeded after withdrawal of the treatment, they were unable to recover their viability, indicating the presence of a stable modulation, chronic and therefore probably at the genomic level.

Whereas some of tumor tissue cells have the ability to proliferate and form new tumors, results, such as inhibition of clonogenic capacity along with the recovery of cellular viability loss after the withdrawal of the treatment could minimize the probability of tumor recurrence and, therefore, have significant implications for the development of therapeutic strategies for the tumor studied.

The study of the mechanism of cell death induced by the treatment used is also a highly relevant criterium. Apoptosis was primarily described as a series of cellular morphological changes that occur in the absence of inflammation, but has been redefined on the basis of molecular events that can be initiated through an extrinsic pathway or by an intrinsic pathway triggered by leakage of cytochrome $c$ from mitochondria and activation of caspases (Budihardjo et al., 1999).
The most important morphological feature of apoptosis is the condensation of chromatin and it has been assumed that this may reflect the oligonucleosomal fragmentation pattern (Wyllie, 1992). In our results, the analysis of nuclear morphology by using fluorescent dye Hoechst ${ }^{\circledR} 33258$ revealed a greater chromatin condensation in the treated cells, patterns consistent with apoptotic cell death. Moreover, the data obtained through flow cytometry and double staining for annexin $\mathrm{V} /$ propidium iodide showed a predominantly cell death by apoptosis in the SiHa cells treated with the E. uniflora aqueous crude extract for 48 hours.

Thus, based on the results described herein we can conclude that the aqueous crude extract of E. uniflora is able to change significantly both the viability of human cervical cancer cells, such as migration ability, adhesion, formation of colonies and recovery capacity after withdrawal of the treatment, without altering the viability of non-tumor cells. All this information plus the finding of an apoptosis mediated cell death, suggest a potential antineoplastic effect of the plant extract. However, more studies are indeed needed for the identification of the compounds responsible for the biological effects observed here, as well as clinical trials to study its potential as a new therapeutic alternative for human cervical cancer.

\section{COMPETING INTERESTS}

The authors declare no competing interests relating to the content of this manuscript.

\section{ACKNOWLEDGEMENTS}

The authors are grateful to the Brazilian agencies FAPERGS and CNPq for financial support. Special thanks to Luisa L. Villa PhD (ICESP, School of Medicine, University of São Paulo) and Silvya S. Maria-Engler PhD (School of Pharmaceutical Sciences, University of São Paulo) for providing the $\mathrm{HaCaT}$ cell line used in the study.

\section{REFERENCES}

Alice CB, Vargas VMF, Silva GAAB, de Siqueira NCS, Schapoval EES, Gleye J, et al. Screening of plants used in south Brazilian folk medicine. J Ethnopharmacol. 1991;35(2):165-171.

Amorim ACL, Lima CKF, Hovell AMC, Miranda ALP, Rezende $\mathrm{CM}$. Antinociceptive and hypothermic evaluation of the leaf essential oil and isolated terpenoids from Eugenia uniflora L. (Brazilian Pitanga). Phytomedicine. 2009;16(10):923-928. 
Bandoni AL, Mendiondo ME, Rondina RVD, Coussio JD. Survey of Argentine medicinal plants. I. Folklore and phytochemical screening. Lloydia. 1972;35(1):69-80.

Bendas G, Borsig L. Cancer cell adhesion and metastasis: Selectins, integrins, and the inhibitory potential of heparins. Int J Cell Biol. 2012;2012:676731.

Bouzada MLM, Fabri RL, Nogueira M, Konno TUP, Duarte GG, Scio E. Antibacterial, cytotoxic and phytochemical screening of some traditional medicinal plants in Brazil. Pharm Biol. 2009;47(1):44-52.

Brasil. Ministério da Saúde, Instituto Nacional de Câncer José Alencar Gomes da Silva - INCA. Estimativa 2016: incidência de câncer no Brasil. Rio de Janeiro (RJ): Ministério da Saúde, 2015. [cited 2017 ago 8]. 126 p. Available from: http://www.inca.gov. br/bvscontrolecancer/publicacoes/edicao/Estimativa_2016.pdf.

Budihardjo I, Oliver H, Lutter M, Luo X, Wang X. Biochemical pathways of caspase activation during apoptosis. Ann Rev Cell Dev Biol. 1999;15:269-290.

Cacciola F, Jandera P, Hajdú Z, Česla P, Mondello L. Comprehensive two-dimensional liquid chromatography with parallel gradients for separation of phenolic and flavone antioxidants. J Chromatogr A. 2007;1149(1):73-87.

Consolini AE, Sarubbio MG. Pharmacological effects of Eugenia uniflora (Myrtaceae) aqueous crude extract on rat's heart. J Ethnopharmacol. 2002;81(1):57-63.

Ferro E, Schinini A, Maldonado M, Rosner J, Hirschmann GS. Eugenia uniflora leaf extract and lipid metabolism in Cebus apella monkeys. J Ethnopharmacol. 1988;24(2):321-325.

Fiuza TS, Rezende M, Sabóia-Morais S. Caracterização farmacognóstica das folhas de Eugenia uniflora L.(Myrtaceae). Rev Eletrônica Farm. 2008;5(2):21-31.

Formica JV, Regelson W. Review of the biology of quercetin and related bioflavonoids. Food Chem Toxicol. 1995;33(12):10611080 .

Franken NP, Rodermond HM, Stap J, Haveman J, van Bree C. Clonogenic assay of cells in vitro. Nat Protoc. 2006;1(5):23152319.

Jacob RA, Burri BJ. Oxidative damage and defense. Am J Clin Nutr. 1996;63(6):985S-990S.
Lee MH, Chiou JF, Yen KY, Yang LL. EBV DNA polymerase inhibition of tannins from Eugenia uniflora. Cancer Lett. 2000;154(2):131-136.

Liang CC, Park AY, Guan JL. In vitro scratch assay: a convenient and inexpensive method for analysis of cell migration in vitro. Nat Protoc. 2007;2(2):329-333.

Lima VLAG, Mélo EA, Lima DES. Efeito da luz e da temperatura de congelamento sobre a estabilidade das antocianinas da pitanga roxa. Ciência Tecnol Aliment. 2005;25(1):92-94.

Lima VLAG de, Mélo EA, Lima DES. Fenólicos e carotenóides totais em pitanga. Sci Agric. 2002;59(3):447-450.

Mabuchi S, Kozasa K, Kimura T. Radical hysterectomy after radiotherapy for recurrent or persistent cervical cancer. Int $\mathrm{J}$ Gynaecol Obstet. 2017 (in press).

Mello PA, Filippi-Chiela EC, Nascimento J, Beckenkamp A, Santana DB, Kipper F, et al. Adenosine uptake is the major effector of extracellular ATP toxicity in human cervical cancer cells. Mol Biol Cell. 2014;25(19):2905-2918.

Parkin DM, Bray F. Chapter 2: The burden of HPV-related cancers. Vaccine. 2006; 24(3):11-25.

Paschos KA, Canovas D, Bird NC. The role of cell adhesion molecules in the progression of colorectal cancer and the development of liver metastasis. Cell Signal. 2009;21(5):665674.

Rattmann YD, De Souza LM, Malquevicz-Paiva SM, Dartora N, Sassaki GL, Gorin PAJ, et al. Analysis of flavonoids from eugenia uniflora leaves and its protective effect against murine sepsis. Evid Based Complement Alternat Med. 2012;2012:1-9.

Reynertson KA, Basile MJ, Kennelly EJ. Antioxidant potential of seven myrtaceous fruits. Ethnobot Res Appl. 2005;3:25-35.

Rodriguez LG, Wu X, Guan JL. Wound-healing assay. Methods Mol Biol. 2005;294:23-29.

Schapoval EES, Silveira SM, Miranda ML, Alice CB, Henriques AT. Evaluation of some pharmacological activities of Eugenia uniflora L. J Ethnopharmacol. 1994;44(3):137-142.

Siegel RL, Miller KD, Jemal A. Cancer statistics, 2016. CA Cancer J Clin. 2016;66(1):7-30. 
Simoes CMO. Farmacognosia, da planta ao medicamento. Porto Alegre: Editora da UFRGS; 2006.

Slowing K, Carretero E, Villar A. Anti-inflammatory activity of leaf extracts of Eugenia jambos in rats. J Ethnopharmacol. 1994;43(1):9-11.

Soutter WP, Sasieni P, Panoskaltsis T. Long-term risk of invasive cervical cancer after treatment of squamous cervical intraepithelial neoplasia. Int J Cancer. 2006;118(8):2048-2055.

Walboomers JMM, Jacobs MV, Manos MM, Bosch FX, Kummer JA, Shah KV, et al. Human papillomavirus is a necessary cause of invasive cervical cancer worldwide. J Pathol. 1999;189(1):12-19.
Wyllie AH. Apoptosis and the regulation of cell numbers in normal and neoplastic tissues: an overview. Cancer Metastasis Rev. 1992;11(2):95-103.

Yamaguchi H, Wyckoff J, Condeelis J. Cell migration in tumors. Curr Opin Cell Biol. 2005;17(5):559-564.

Received for publication on $24^{\text {th }}$ May 2017 Accepted for publication on $27^{\text {th }}$ September 2017 